Purdue University Purdue e-Pubs

\title{
Reviewing the Current State of Library Support for Open Educational Resources
}

\author{
Jason B. Reed \\ reed252@purdue.edu \\ Benjamin Jahre \\ Lafayette College, jahreb@lafayette.edu
}

Follow this and additional works at: https://docs.lib.purdue.edu/lib_fsdocs

Part of the Library and Information Science Commons

\section{Recommended Citation}

Reed, Jason B. and Jahre, Benjamin, "Reviewing the Current State of Library Support for Open Educational Resources" (2019). Libraries Faculty and Staff Scholarship and Research. Paper 219.

http://dx.doi.org/10.1080/01462679.2019.1588181 


\section{Reviewing the Current State of Library Support for Open Educational Resources}

Academic institutions around the United States are facing pressure to reduce tuition and fees in order to keep higher education accessible. Open Education Resources (OER) is one attempt by academic institutions to provide high quality education resources at a lower cost to students, by replacing traditional textbooks with freely available or low cost materials. Libraries as information experts play an active role in the implementation of OER. This article looks at the current state of OER and what potential impacts OER will have on libraries.

Keywords: open educational resources, OER, textbooks, affordability, higher education, course materials, library collections

\section{INTRODUCTION}

There are many challenges that higher education will need to address in the near future. One of the most pressing is the student debt crisis. In 2010, student loan debt surpassed total credit card debt and as of the second quarter of 2018, student loans account for 1.5 trillion dollars in consumer credit outstanding (Kantrowitz 2010; The Federal Reserve 2018). The issue of student debt has, in part, been driven by rising tuition, fees, and room and board. According to the U.S. Department of Education (2018), prices for undergraduate students have risen 34 percent at public universities and 26 percent at private universities between the 2005/06 and 2015/16 academic years, the most recent data available. These obligations are having major impacts on students' quality of life during college and after graduation. A U.S. Department of Education Report found that only 41.3 percent of first-time post-secondary students who began in 1995/96 had repaid or closed their loans without default twenty years after starting their postsecondary education (Woo et al. 2017). Relatedly, a study by NerdWallet found that the average retirement age for current students is expected to increase by thirteen years, from sixty-two to seventy-five 
(O’Shea 2015). The situation can be even direr for those who go on to pursue advanced degrees. For example pharmacy graduates on average have over $\$ 100,000$ in debt upon graduation and students who attended pharmacy programs at private schools are at nearly $\$ 200,000$ in debt (Ulbrich and Kirk 2017). Failure to address this crisis could result in a decrease in the number of students pursuing a college education, an increase in enrollment in for-profit institutions, or both.

In 2017, for the first time ever, more than 50 percent of public institutions in the United States received a majority of their funding from student tuition rather than state appropriations (Laderman, Carlson, and State Higher Education Executive Officers Association 2018). This change is especially notable in light of the fact that there has been an average increase in state appropriations support over the last five years. Even at private institutions that do not receive state funding, tuitions have been increasing steadily (U.S. Department of Education, National Center for Education Statistics 2018). Rising tuition costs are a result of a variety of factors. Colleges raise costs to pay for new buildings or to replace aging infrastructure; to provide a wider array of campus services; to keep pace with new and updated technologies; or, sometimes simply to maintain a level of status and exclusivity. Another factor contributing to rising costs is universities, libraries, or students themselves purchasing educational materials in the form of research databases, educational software, and textbooks. While the cost for research materials and often educational software are in part passed along to students as part of their tuition and/or fees, the most transparent cost is the money students must pay for textbooks, which is an added cost on top of their increasing yearly tuition and fees.

Many higher education institutions that have observed these trends either have begun, or are beginning, to promote the use of Open Educational Resources (OER) as an alternative to traditional, expensive textbooks. Academic libraries are often part of these OER initiatives and 
are well placed going forward to help drive their adaptation or expansion. This article will examine the current state of OER, with an emphasis on the role academic libraries have played, how OERs have and will continue to affect academic library collections.

\section{WHAT IS OER}

The concept of OER is still in the process of being universally defined. Most global definitions of OER require the use of freely available educational materials. For example, UNESCO defines OER as "teaching, learning or research materials that are in the public domain or released with an intellectual property license that allows for free use, adaptation, and distribution" (UNESCO n.d.). By contrast, higher education institutions in the United States, which are the focus of this article, do not have a commonly agreed definition of what constitutes an OER. Some institutions, such as the University of Hawaii, use the definition provided by the Hewlett Foundation:

Open Educational Resources are teaching, learning and research materials in any medium digital or otherwise - that reside in the public domain or have been released under an open license that permits no-cost access, use, adaptation and redistribution by others with no or limited restrictions (William + Flora Hewlett Foundation n.d.).

Others use the Scholarly Publishing and Academic Resources Coalition's (SPARC) definition:

Open Educational Resources (OER), which are teaching, learning, and research resources that are free of cost and access barriers, and which also carry legal permission for open use. Generally, this permission is granted by use of an open license (for example, Creative Commons licenses) which allows anyone to freely use, adapt and share the resourceanytime, anywhere. "Open" permissions are typically defined in terms of the " $5 \mathrm{R}$ 's": users are free to Retain, Reuse, Revise, Remix and Redistribute these educational materials. (“Open Education” n.d.). 
Some universities use their own definition to state that OER materials must be freely available, for example Fort Hays State University (n.d.). Alternatively some institutions, such as Penn State University, have adopted an OER definition that allows for the use of materials that have "little or no cost" (Penn State University n.d.). The University of Houston's OER grants allow for "assembly of freely available or library sponsored resources" (University of Houston Libraries n.d.). The main practical difference in these standards is that some institutions count materials licensed by the libraries/institution to qualify as OERs even though these materials are not truly open. While this can be helpful for faculty and students within a local context, it does not align with the more commonly accepted definitions listed. It can also contribute to confusion about what OER means and limit the ability of faculty from other institutions to adopt that material for their classes. Regardless of the exact wording and definition of what constitutes an OER, both international and US OER standards recognize three phases of OER: adopt, adapt, and create. "Adopt" refers to situations where instructors and/or academic units take an existing resource and implement it into their course. "Adapt" goes one step further and refers to situations where an instructor takes an existing OER and modifies certain aspects of the material to better fit their course objectives. The ability to adapt is dependent on the original OER creator using a creative commons license that allows for modification with attribution. "Create" describes situations where an OER is built from scratch. Creators may use existing open textbooks or other freely available learning objects as guides, but the final product is assembled or created from these materials and is licensed for free use from the outset. "Create" represents the most control over the OER, but it also requires the largest investment of time and effort on the part of the creator. 
Whatever the approach, OER is intended to increase access to educational resources by reducing or removing financial barriers. Though the costs for textbooks varies wildly depending on the discipline and publisher, it is estimated that students save one hundred dollars per class that uses an OER instead of a traditional textbook (openoregon 2017). This could translate to a savings of up to $\$ 3,200$ over a four year undergraduate student's academic career, assuming all of their courses incorporated OERs. This money could then be spent on other items that cause financial strain for undergraduates, such as meals, laundry, travel, other incidental expenses.

The impact that textbook costs have on students is underscored by the role students have played in driving the OER movement to date. Several institutional affordable textbook initiatives have been led by or benefited from the advocacy and support of their students (Christie, Pollitz, and Middleton 2009; Davis et al. 2016; Lashley et al. 2017; Woodward 2017). The Student Public Interest Research Groups (PIRGs) has "investigated publisher practices and the student experience in the textbook market" for well over a decade (Vitez 2018, 5). Student PIRGs has surveyed thousands of students and faculty members in an effort to understand the strains textbooks costs have on students, and to collect actionable data that can be used to advocate for OER. In their 2018 report, Student PIRGs highlighted how the bundling of print textbooks with access codes for online content (such as homework modules and quizzes) removes the ability of students to seek savings through the used textbook market (Vitez 2018).

The work students have done to promote textbook affordability, whether on a local or a national scale, is emblematic of how implementation of and support for OER requires a collaborative effort between instructors, students, and campus units. Currently the units that 
most often support OER on campuses are libraries, IT departments, centers for teaching/learning/scholarship, bookstores, and student governments. Supporting OER efforts represents a great opportunity for libraries to help shape the path that OER will take on campus. They can use that "voice at the table" to encourage the incorporation of open access materials into new OERs and they can offer their expertise in discovery to help identify existing materials.

It is important to note that some academic libraries make it a policy to avoid buying textbooks, primarily for some of the same reasons that have driven the OER movement to date; namely, the fact that college textbooks are expensive and tend to go obsolete quickly. However, those libraries that do purchase textbooks to support teaching on campus would be able to direct that money for use elsewhere, if OER was adopted in those particular classes. The support of OER is also a great opportunity for libraries to have discussions with students about how libraries support the overall educational mission of the institution. OERs represent an opportunity for libraries to highlight a part of their collection -- assuming the libraries incorporate OERs either into institutional repositories or index them in the online catalog -- that could positively impact all students. OERs could provide an excellent opportunity to create goodwill with current students/future potential donors and with current donors who are interested in supporting initiatives that will directly benefit students.

\section{CURRENT STATE OF OER}

At present OERs have been implemented by a diverse group of higher education institutions, including community colleges, public universities, private universities, state systems, and consortiums (“Connect OER - SPARC” n.d.). OERs have proven valuable enough that a few states, including Hawaii, California, and Washington, have passed laws supporting the 
implementation of OERs at publicly funded universities and colleges (“OER State Policy

Tracker" n.d.). OER have even been recognized by the U.S. Congress which included 5 million dollars for an open textbook grant program as part of the FY18 omnibus grant program (Allen, 2018).

A recent scan of OER policies (as listed in the SPARC Connect OER Directory online database) reveals that most institutions engaging with OER offer financial support to entice and/or compensate faculty for their time and effort in implementing OERs into their courses (Connect OER - SPARC n.d.). The level of support ranges from $\$ 200$ to $\$ 6,000$. For example the University of Montana offers small stipends (e.g. \$200) to faculty "to provide a written review of an existing open textbook" (“OER Review Grant” n.d.). The Virginia Tech Libraries offer "up to $\$ 3,000$ to faculty or faculty groups...to adopt a new curricular resource strategy" (Walz n.d.). At the high end, OpenOregon (2018) provides up to $\$ 6,000$ to faculty who author, i.e. create, an OER. Grant amounts often depend on the time faculty will need to spend on investigating and/or implementing the OER for their course. Typically those creating OERs receive larger incentives than those who adopt or adapt, since creation represents a more significant investment of time and labor. Some examples of these types of programs can be found at University of Kansas (Emmett, Bolick, and Reed 2016), University of Massachusetts Amherst ("UMass Library Open Education Initiative" n.d.), and Macalester College (Joslin n.d.).

Other institutions, in lieu of financial support, offer additional forms of support in helping faculty discover existing OERs they can adopt or adapt for their class. For example Washtenaw Community College library provides a guide with extensive information on the types of support available for finding or creating an OER, but does not have any financial support listed (McCarthy n.d.; Smith and Lee 2017, 109). The financial support that does exist for incentive 
programs has come from a variety of sources including student government allocations, private donations made to the university for OERs, funds from campus administration, funds from the library, and/or grants from government agencies or private foundations such as the Hewlett Foundation.

In addition to financial benefits for students who have OERs in their classes, research has shown that student performance is the same or better when an OER is used in lieu of a traditional textbook (Colvard, Watson, and Park 2018). Student grades in classes that move to OERs tend to remain level or even improve, primarily because students have more immediate access to the text, and there is less chance for a student not to do the readings because they do not want to pay for the textbook (Cooney 2017; Fischer et al. 2015; Robinson 2015). Students also often report being more engaged in class, because they have immediate access to their textbook in the classroom, as opposed to leaving their textbooks at home because they are too heavy to carry around (Feldstein et al. 2012). Student enrollment in/completion of courses also tends to be greater for OER courses (Colvard, Watson, and Park 2018; Cooney 2017; Fischer et al. 2015).

\section{OPPORTUNITIES AND CHALLENGES}

Despite the benefits for students, two big questions/obstacles, viability and sustainability, remain in regards to OER's chances of widespread adoption. First: will OER remain in flux similar to the Open Access movement, or will the desire of universities to remain competitive by offering students low cost materials help spur the continuation of OER creation and curation? The Open Access (OA) movement has played a major role in informing the OER movement. The two are founded on the same basic principle: making knowledge and information universally accessible by removing the financial barriers that exist in the forms of highly inflated journal subscription costs and textbook purchase prices. A concern for OER is that while OA began with this virtuous 
charge, it was quickly bogged down by concerns about impact relating to promotion and tenure, issues of quality in presentation, and, later, the quagmire of predatory journals. Second: is the current OER model of providing grants to OER adopters, adapters, and creators sustainable? The growing demand for lower tuitions could have major implications for campus-wide budgets, which would in turn likely impact the already tenuous budget situations many libraries face. As OER grows in popularity, libraries will need to consider carefully where to allocate their resources, especially considering that the spread of OER usage could impact the use of library subscribed content.

One potential sustainable model is state governments and/or university administrations requiring that the costs for textbooks be included as part of a student's tuition and fees (Annand, 2015). This decision would bring transparency to the true cost of pursuing a higher education and provide an incentive to universities, state systems, or consortiums to create, maintain, and use OERs. Implementing OER programs would provide an opportunity for universities and colleges to recruit students by demonstrating how much money students would save on textbooks when compared to universities using traditional texts. Additionally, by making OERs a campus priority, faculty who create or adapt OERs would be able to cite this work in their promotion and tenure documents as an example of how they contributed to the institution's strategic plan. Thus, even if financial support for using OERs begins to dry up, faculty will have an additional incentive to take the time and effort to engage with OERs.

\section{Growth}

Despite these concerns, we expect that OERs will continue to gain traction on college campuses. This continued growth has the potential to impact libraries, particularly in regards to collections and personnel. At campuses that focus on incentivization programs, either for the adoption or 
adaptation of existing freely available OERs or the creation of unique material, libraries may find themselves caught between two worlds. If faculty are receiving financial support at the administrative level for adapting, adopting, or creating resources, the library budget is one place the administration may look for the money to support campus OER efforts. This concern, while important, is not the biggest potential hurdle libraries may face in regards to widespread OER use on campus.

\section{Relationships With Publishers}

The bigger issue for academic libraries to consider is how OER will affect relationships with publishers. Textbook publishers are beginning to recognize the potential threat to the market posed by OER. As a result, some publishers are starting to promote their own affordable textbook programs, often referred to as "inclusive access". These models typically take one of two forms: either a discounted textbook cost is built into each student's course fees (which they can opt out of) and the students receive leased access to an online version of the text; or, libraries pay for sitewide access to a suite of e-books or electronic textbooks, which are then made available to faculty and students. These approaches have the benefit of providing access to material from publishers that faculty are already familiar with, such as MacMillan or Springer, while still saving students money. Weighed against this benefit is the concern that the opt-out inclusive access model is not really all that inclusive, and in fact presents new barriers to students, such as not being able to retain access to the text beyond the lease period, or forcing them out of recouping some of the cost in the used textbook market once the course is complete (Bell and Salem 2017; Jhangiani 2017).

The obvious downside of the site wide inclusive access model is that the library will likely become responsible for textbook costs in addition to pre-existing collections expenditures. 
At some institutions libraries may have their funding reduced to help cover the cost of a campus wide textbook subscription, as administrations look for ways to cover these expenditures without passing the costs along to students in the form of tuition and fees. It is of course possible that some libraries' funding/budgets will be unaffected by this outcome. It is also possible that in some other cases libraries will be asked to split these new costs with other entities on campus (such as the bookstore or student government), or that these other entities will assume full responsibility for textbook packages. However, due to the library's historical experience in negotiating and managing large digital collections with publishers, it is hard to envision a landscape other than one where the library must take on primary responsibility for online textbook package costs in all but a few cases. These costs will likely be "hidden" to most users, much like with electronic journal packages, in that they are easily accessible without it being clear that the library and/or university is paying for access to these items. Or the libraries will need to make cuts in other areas in order to account for the additional strain placed on their collections budgets by these new expenditures.

\section{Impacts on Librarians}

An increase in OER use on college campuses may also present an opportunity for librarians to develop closer relationships with their faculty colleagues. As more faculty see the merits of OER, or are compelled to consider OER due to student and/or administrative pressure, we expect that they will come to rely more closely on their liaison librarians to partner in the selection or creation of OERs. These collaborations may start simply, with librarians suggesting to faculty where to search for OERs. The options for discovering open materials are already becoming unwieldy, and unless a single discovery resource (e.g., the Mason OER Metafinder) takes the 
fore, it is likely that many faculty will appreciate help in knowing where to search, and how to locate the best materials within these OER repositories.

Faculty who change a class to move away from expensive textbooks may also look to partner with librarians on how to use library-owned content, such as journal articles and e-books, to supplement class readings. This kind of work could include consultations on e-book access permissions or how to work with the reserves department to create physical or electronic course reserves. These conversations may naturally lead to questions of how to navigate copyright issues, whether in relation to the use of subscribed content, or in the adoption or remixing of OERs generally. The intention of true OERs is to be licensed under CC-BY terms, but faculty may either not be aware of this or know exactly what such a license entails.

Liaison and instruction librarians can also provide value to faculty by working together on course design. One of the major current hurdles to OER adoption in higher education is that for existing courses, such a move often requires a lot of work on the part of the instructor to revise lecture slides, in-class exercises, and assignments. Librarians can offer their expertise in pedagogy and information literacy to collaborate with faculty in modifying courses that aim to integrate new materials. These collaborations could then naturally extend to assessment. If librarians can keep abreast of the ways to measure the impact of OER adoption -- in terms of money saved, student performance on assignments, and student satisfaction with the course, they can be leaders in justifying OER movements on campus.

By assisting in proving the value of OER adoption, librarians can help faculty show alignment with the institution's strategic initiative in their promotion and tenure documents. This kind of support, in turn, may influence faculty perceptions of librarians, bolster their partnerships, and perhaps lead to faculty becoming stronger and more vocal advocates for the 
library in general. If this can be accomplished, libraries may see themselves rewarded with more attention and increased budgets from administration.

The spread of OERs could also have significant impacts on the work of other librarians besides public services librarians who most often work directly with faculty. An increase in OER usage should go hand in hand with a decrease in physical course reserves, which would free up time and effort for access services staff. Instruction librarians will be able to access the readings of the OER-based classes they work with, and will thus be able to tailor more closely their instruction to the work of those classes. Metadata librarians will be able to use their expertise to help OER creators make their materials discoverable by other faculty. Copyright librarians can help faculty choose the best creative commons license for their materials, and/or navigate issues of copyright when adopting or adapting existing resources.

\section{CONCLUSION}

The best way to get ahead of this potential future is for librarians to aggressively promote the adoption of OER in its truest form, i.e. to advocate for faculty to shed all paid material when bringing OERs into a course. Many faculty use publisher supplied homework sets, quizzes, etc., which are often expensive in their own right. Therefore, it may not be enough simply to encourage faculty to do away with expensive textbooks. If librarians can alse-make compelling cases that faculty should either create their own assignment/exam packs or adopt freely available options, this potential scenario of becoming further tied to inflationary pricing models can be avoided.

The long-term success of the OER movement will be determined by a combination of many factors such as quality of the materials, sustained advocacy and promotion, and stable funding and administrative support. There will be challenges to overcome, such as dispelling 
misunderstandings about OERs, convincing resistant faculty of the merits of the movement, and avoiding scenarios where for-profit publishers muddy the waters with commercial OER plans. However, by promoting OERs as a high quality alternative to expensive texts, libraries can put themselves in a strong position to support increased access to knowledge and information while at the same time evolving their collections and position responsibilities. Libraries that can make themselves central partners in collaborative institution- or state-wide OER programs can ensure that they will be part of the long term conversation around OER and maintain their role as the information experts on campus. If these steps are taken, we feel confident that libraries can improve their collections ecosystem while simultaneously helping to solidify the OER movement in higher education.

\section{Reference List}

Allen, Nicole. 2018. “Congress Funds \$5 Million Open Textbook Grant Program in 2018 Spending Bill.” SPARC. March 20, 2018. https://sparcopen.org/news/2018/opentextbooks-fy18/.

Annand, David. 2015. "Developing a Sustainable Financial Model in Higher Education for Open Educational Resources." International Review of Research in Open and Distributed Learning 16 (5): 1-15.

Bell, Steven J., and Joseph A. Salem. 2017. "It's Up to the Librarians: Establishing A Statewide OER Initiative.” Pennsylvania Libraries: Research \& Practice 5 (2): 77-82. https://doi.org/10.5195/palrap.2017.166.

Christie, Anne, John H. Pollitz, and Cheryl Middleton. 2009. "Student Strategies for Coping with Textbook Costs and the Role of Library Course Reserves." Portal: Libraries and the Academy 9 (4): 491-510. https://doi.org/10.1353/pla.0.0077.

Colvard, Nicholas B, C Edward Watson, and Hyojin Park. 2018. "The Impact of Open Educational Resources on Various Student Success Metrics.” International Journal of Teaching and Learning in Higher Education 30 (2): 262-76.

"Connect OER - SPARC.” n.d. Accessed July 16, 2018. https://connect.sparcopen.org/directory/. Cooney, Cailean. 2017. "What Impacts Do OER Have on Students? Students Share Their Experiences with a Health Psychology OER at New York City College of Technology." International Review of Research in Open and Distributed Learning 18 (4): 155-78.

Davis, Erin, Dory Cochran, Britt Fagerheim, and Becky Thoms. 2016. "Enhancing Teaching and Learning: Libraries and Open Educational Resources in the Classroom.” Public Services Quarterly 12 (1): 22-35. 
Emmett, Ada, Josh Bolick, and Marianne Reed. 2016. "KU Libraries' OER Grant Initiative." July 20, 2016. https://openaccess.ku.edu/grant.

Feldstein, Andrew, Mirta Martin, Amy Hudson, Kiara Warren, John Hilton, and David Wiley. 2012. "Open Textbooks and Increased Student Access and Outcomes." European Journal of Open, Distance and E-Learning. https://eric.ed.gov/?id=EJ992490.

Fischer, Lane, John Hilton, T. Jared Robinson, and David A. Wiley. 2015. "A Multi-Institutional Study of the Impact of Open Textbook Adoption on the Learning Outcomes of PostSecondary Students." Journal of Computing in Higher Education 27 (3): 159-72. https://doi.org/10.1007/s12528-015-9101-x.

Fort Hays State University. n.d. "Open Textbook Grant Program - Fort Hays State University." Accessed February 11, 2019. https://www.fhsu.edu/oer/otgp/index\#oer.

Jhangiani, Rajiv. 2017. “Just How Inclusive Are 'Inclusive Access' e-Textbook Programs?” Rajiv Jhangiani, Ph.D. (blog). June 29, 2017. http://thatpsychprof.com/just-howinclusive-are-inclusive-access-programs/.

Joslin, Ron. n.d. “Open Educational Resources (OER): A Quick Guide.” Accessed February 8, 2019. https://libguides.macalester.edu/c.php?g=655167\&p=4598975.

Kantrowitz, Mark. 2010. “Total College Debt Now Exceeds Total Credit Card Debt.” Fastweb. August 11, 2010. https://www.fastweb.com/financial-aid/articles/total-college-debt-nowexceeds-total-credit-card-debt.

Laderman, Sophia, Carlson, Andrew, and State Higher Education Executive Officers Association. 2018. "State Higher Education Finance (SHEF): FY 2017." State Higher Education Executive Officers Association. http://www.sheeo.org/sites/default/files/projectfiles/SHEEO_SHEF_FY2017_FINAL.pdf.

Lashley, Jonathan, Rebel Cummings-Sauls, Andrew B. Bennett, and Brian L. Lindshield. 2017. "Cultivating Textbook Alternatives From the Ground Up: One Public University's Sustainable Model for Open and Alternative Educational Resource Proliferation." The International Review of Research in Open and Distributed Learning 18 (4). https://doi.org/10.19173/irrodl.v18i4.3010.

McCarthy, Sandy. n.d. “Open Educational Resources: WCC.” Accessed February 8, 2019. //libguides.wccnet.edu/c.php?g=763784\&p=5477977.

“OER Review Grant.” n.d. Accessed February 8, 2019. https://www.lib.umt.edu/oer/reviewgrant.php.

“OER State Policy Tracker.” n.d. SPARC. Accessed October 10, 2018. https://sparcopen.org/our-work/state-policy-tracking/.

“Open Education.” n.d. SPARC. Accessed October 10, 2018. https://sparcopen.org/openeducation/.

OpenOregon. 2018. “Call for Proposals: Open Educational Resources Grants.” March 20, 2018. https://openoregon.org/call-for-proposals-open-educational-resources-grants-2/.

OpenOregon. 2017. "Is the Average Cost of a Textbook \$100? - Openoregon.Org." February 17, 2017. http://openoregon.org/is-the-average-cost-of-a-textbook-100/.

O'Shea, Arielle. 2015. "New Grads Won't Be Able to Retire Until 75, Study Finds." NerdWallet (blog). 2015. https://www.nerdwallet.com/blog/investing/millennial-grad-retirement-ageis-75/.

Penn State University. n.d. “OER Definitions.” Accessed June 25, 2018. http://oer.psu.edu/oerdefinitions/. 
Robinson, Thomas. 2015. "The Effects of Open Educational Resource Adoption on Measures of Post-Secondary Student Success." All Theses and Dissertations, May. https://scholarsarchive.byu.edu/etd/5815.

Smith, Brenda, and Leva Lee. 2017. "Librarians and OER: Cultivating a Community of Practice to Be More Effective Advocates.” Journal of Library \& Information Services In Distance Learning 11 (1): 106-22.

The Federal Reserve. 2018. "The Fed - Consumer Credit - G.19.” 2018. https://www.federalreserve.gov/releases/g19/HIST/cc_hist_memo_levels.html.

Ulbrich, Timothy R., and Loren M. Kirk. 2017. "It's Time to Broaden the Conversation About the Student Debt Crisis Beyond Rising Tuition Costs." American Journal of Pharmaceutical Education 81 (6). https://doi.org/10.5688/ajpe816101.

“UMass Library Open Education Initiative." n.d. Accessed February 8, 2019. https://www.library.umass.edu/oer/open-education-initiative/.

UNESCO. n.d. “Open Educational Resources | United Nations Educational, Scientific and Cultural Organization.” Accessed October 10, 2018. http://www.unesco.org/new/en/communication-and-information/access-toknowledge/open-educational-resources/.

University of Houston Libraries. n.d. "Incentive Program | University of Houston Libraries." Accessed February 13, 2019. https://libraries.uh.edu/oer/incentive/.

U.S. Department of Education, National Center for Education Statistics. 2018. "Digest of Education Statistics, 2016 (NCES 2017-094).” 2018. https://nces.ed.gov/programs/digest/d16/ch_3.asp.

Vitez, K. 2018. “Open 101. An Action Plan for Affordable Textbooks.” Report by the Student PIRGs. Washington, DC,[Online], www. Studentpirgs. Org/Textbooks.

Walz, Anita. n.d. "Research Guides: Open Education: Faculty Open Education Initiative Grants." Accessed February 8, 2019. https://guides.lib.vt.edu/oer/grants.

William + Flora Hewlett Foundation. n.d. "Open Educational Resources." Hewlett Foundation (blog). Accessed October 10, 2018. https://hewlett.org/strategy/open-educationalresources/.

Woo, Jennie H, Bentz, Alexander H., Lew, Stephen, Velez, Erin Dunlop, Smith, Nichole, and RTI International. 2017. "Repayment of Student Loans as of 2015 Among 1995-96 and 2003-04 First-Time Beginning Students: First Look.” NCES 2018-410. U.S. Department of Education.

Woodward, Kristin M. 2017. "Building a Path to College Success: Advocacy, Discovery and OER Adoption in Emerging Educational Models.” Journal of Library \& Information Services in Distance Learning 11 (1-2): 206-12. https://doi.org/10.1080/1533290X.2016.1232053. 